\title{
Defects of non-loadbearing masonry walls due to partial basal supports
}

\author{
R. Da Silva Vicente ${ }^{a, *}$, J.A.R. Mendes da Silva ${ }^{\text {b,1 }}$ \\ a Department of Civil Engineering, University of Aveiro, 3810 Aveiro, Portugal \\ b Department of Civil Engineering, University of Coimbra, 3030-290 Coimbra, Portugal
}

Received 4 March 2005; received in revised form 6 March 2006; accepted 31 May 2006

Available online 20 September 2006

\begin{abstract}
The attempts to reduce heat transmission heterogeneity all over the external surface of building envelopes include several recommendations about external protection of concrete structures with thin clay brick walls. This procedure was extensively adopted in Portugal during the last ten years in consequence of the new national thermal code. This practice has generated several defects in consequence of the insufficient technological knowledge in this domain. This work analyses some of those defects adopting an experimental and a numerical approach, using the traditional Portuguese clay brick with a high percentage of horizontal voids.
\end{abstract}

(C) 2006 Elsevier Ltd. All rights reserved.

Keywords: Masonry walls; Cracking; Strength; Stress; Strain

\section{Introduction}

Vertical building enclosures in Portugal include, very often, non-loadbearing masonry walls, using horizontally hollowed clay bricks. These walls are generally supported by a concrete frame structure of columns, beams and slabs.

Since these walls do not support severe external loads, their design is often negligent and insufficiently detailed. In consequence, several pathological defects can be observed, comprising, in general, loss of water-tightness and cracking.

One of the most recent causes for these defects is the reduced width support of the walls on concrete slabs, in order to minimise thermal bridge effects over internal surfaces, such as mould grow and condensations (internal and external). With this procedure, designers want to protect the concrete frame externally with a thin clay brick slip (normally half width of clay brick) that increases, locally, the thermal resistance.

\footnotetext{
* Corresponding author. Tel.: +351234 370049; fax: +351234370094.

E-mail addresses: romvic@civil.ua.pt (R.Da Silva Vicente),raimundo@ dec.uc.pt (J.A.R. Mendes da Silva).

${ }^{1}$ Tel.: +351 239 797206; fax: +351 239797207.
}

These less and poorly-supported walls are severely cracking and, in worse cases, fall apart.

External solid or perforated clay brick walls are well known by building science and they are correctly built in many countries. However, the problem is quite different when brick resistance is very low and the percentage of horizontal voids is more than $60 \%$ of the section area, delimited by thin clay septums of $8-9$ mm thick.

In this case, cracking can be dramatic, even for very low loads, depending on different support conditions [1].

This paper reports an experimental and numerical work on first cracking and final failure of hollow clay brick walls, with different support conditions. Using clay brick wall samples, monitored with strain gauges and displacement transducers, we have observed and video-recorded cracking and rupture evolution, under vertical centred and eccentric compression loads, with full and partial concrete supports, steel shelf angles supports and heterogeneous mixed supports (brick and concrete).

Numerical simulations of the behaviour of these wall specimens have also been made, using the Finite Element Method, trying to explain the shape and cracking evolution within such complex brick geometry. The paper ends presenting some technological conclusions to obtain better 
masonry brick external walls with horizontally hollowed clay brick, which are quite a traditional solution in some Mediterranean countries.

\section{Portuguese construction and the new thermal code}

\subsection{Building vertical envelope}

A very high percentage of Portuguese buildings constructed during the last 40 years have an orthogonal concrete structure of columns and beams, with internal rigid connections. The structure frames are filled with masonry walls using typical hollow clay bricks (see Fig. 1). Generally, the design of these buildings doesn't require any relevant resistance for the walls, and neglects also their natural contribution to increase building stiffness, that influences the structural response to seismic actions.

Portuguese standards define four hollow clay brick models that are represented in Fig. 2. In spite of the excellent raw materials available and used by national industry, these clay bricks are often very weak, in consequence of their internal geometry. The building envelope is obtained with single or double leaf masonry walls of hollow clay bricks. Double wall leafs are 110 or $150 \mathrm{~mm}$ thick and the ventilated air gap between them is $50-100 \mathrm{~mm}$ wide [2]. It is common to partially fill this air gap with synthetic insulating boards $30-40 \mathrm{~mm}$ thick, reducing heating energy consumption and increasing building comfort levels. The use of wall ties connecting the two leafs of cavity walls is still a very rare practice.

\subsection{Portuguese thermal code and condensation risk}

Traditionally, external masonry of single or double leaf walls were constructed to fill concrete frame cells having the same thickness of structural members (columns and beams) leading to a considerable thermal heterogeneity of façades (with typical $\mathrm{U}$ values of $3.0 \mathrm{~W} / \mathrm{m}^{2} \mathrm{~K}$ across concrete members and $0.5-1.0 \mathrm{~W} / \mathrm{m}^{2} \mathrm{~K} \mathrm{U}$ values across masonry filling panels).

These cold bridges (thermal bridges), associated to reduced and less efficient heating and ventilating systems, represent an enormous risk of local surface condensation. Inside the buildings, the temperature of internal surface of external walls - over structural members - is often below the dewpoint, leading to inevitable condensation and
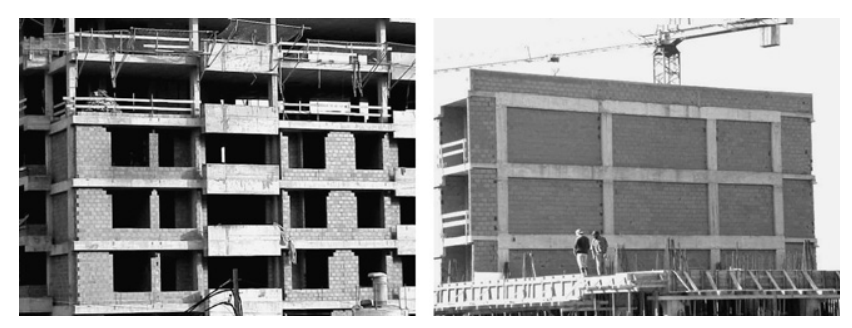

Fig. 1. Typical concrete structure of Portuguese buildings filled with nonloadbearing masonry walls.
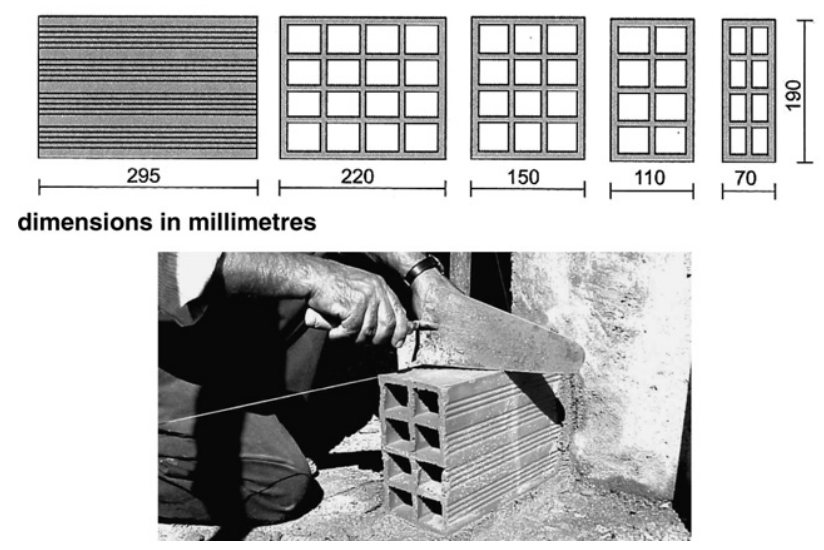

Fig. 2. Portuguese standard models for hollow clay bricks.

mould growing, with aesthetic and health consequences [3].

To solve condensation problems it is necessary to act upon several parameters [4], including the improvement of thermal homogeneity of façades, which is easily reached with external continuous insulating coats, still rare in Portugal. In 1990, the new Portuguese Thermal Code $[5,6]$ suggested, as alternative, the adoption of an additional thermal protection of concrete members of external walls, that could locally increase their resistance, by 0.06 $0.12 \mathrm{~m}^{2} \mathrm{~K} / \mathrm{W}$. In fact, with our climate, this procedure is sufficient to reduce condensation risk to an acceptable level. This new code deals also with several other thermal factors (energy saving, solar gains, inertia role in Winter and Summer, windows protection, etc.) that deeply improved thermal quality and comfort in Portuguese buildings in the last few years.

\subsection{Masonry defects in consequence of thermal bridge correction}

To achieve the goals of the new thermal code, in what concerns the need to increase thermal resistance over concrete members, designers and contractors adopted several methods, based on a quite inconsistent and unknown technology. Among these methods it is more relevant a particular one that promotes an external overhanging of masonry walls $50-80 \mathrm{~mm}$, outwards of the structure surface, that assures an external protection of the concrete members with one or two clay brick voids (increasing thermal resistance as expected, by $0.06 \mathrm{~m}^{2} \mathrm{~K} / \mathrm{W}$ for each layer of brick voids parallel to the concrete surface) and also preserves the alignment and the aspect of the façade.

Unfortunately, this method is frequently adopted without any care for wall tying and without an accurate evaluation of brick resistance and masonry deformation. Fig. 3 shows two case studies where severe cracking occurred, imposing, in the first situation, the demolition and re-construction of the external leaf of the wall. 

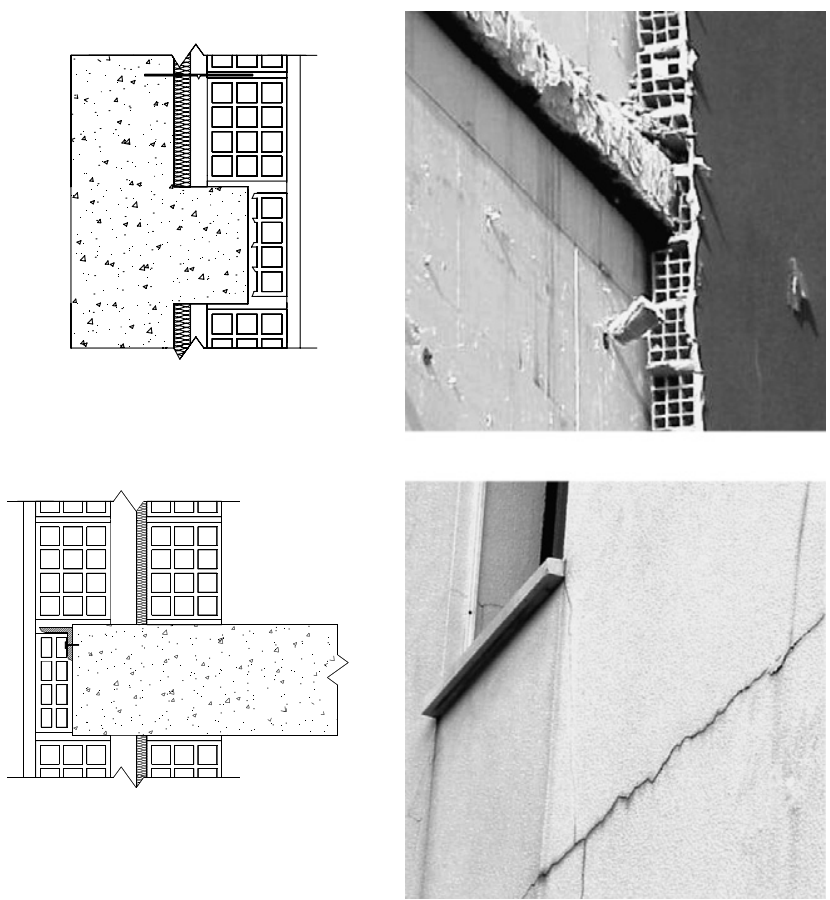

Fig. 3. Two examples of severe mechanical defects resulting from inadequate correction of thermal bridges, using masonry walls partially supported (adapted from [7])

The major cause for the cracking and instability problems observed in several buildings is the reduced width of the support of the walls on the floor slabs or beams. This situation leads to high local stresses which effects are increased by brick internal geometry [8], as revealed in further on.

Other factors can also contribute to aggravate consequences, such as: excessive weight of exterior linings, additional and eccentric loads, wind loads, creep and shrinkage movements of the structure, heat and moisture movements of the masonry, lack of wall ties, lack of technological knowledge and poor workmanship skills (particularly at singular points).

The major defects in this domain are [9]

- Horizontal cracks at slab level, affecting only rigid and adherent linings, or both linings and back wall, resulting from local high stresses or vertical deformation;

- Horizontal cracks at mid-height level between two floor slabs resulting from the bowing phenomena due to transversal deformation (creep), vertical moisture and thermal expansion, structure shrinkage, aggravated by partial, poor and insufficient support conditions;

- Overall stability of wall panel (including falling apart), due to excessive rotation allowed by partial support conditions, thick renders and lack of wall tying;

- Crushing or detachment of brick slips that conceal floor slab levels;

- Loss of water-tightness due to cracking;

- Local shear failure at the lower brick (near concrete floor slab or beam) where the support conditions of the wall (outer leaf) due to thermal bridge correction are reduced by thinning of the wall (brick slips covering concrete) originating cracking at the region of transition of support conditions;

- Vertical cracks near corners and columns, caused by the lack of confined and fixed brickwork covering, more susceptible to expansion-contraction phenomena.

To get some results - step by step - on these new problems in Portuguese buildings, we have started a research program about masonry brick walls supports, to learn more about the

- Type of failure and it is shape evolution against load;

- Failure load and load for first cracking;

- Strain evolution over wall surfaces;

- Vertical displacement of the non-supported surface of the wall;

- Cause-effect relations between cracking, strain development and support conditions.

\section{Experimental work on masonry walls}

\subsection{Scope of experimental work}

Masonry wall testing has been approached in many different ways in Portugal, but not in such a way as treated in this paper. Testing masonry wall specimens built with typical hollow clay bricks and "general purpose" mortar with different support conditions is the subject of a experimental component of a MSc thesis.

Eight types of specimens were tested, with different geometry, support and loading conditions.

\subsection{Laboratory apparatus and experimental procedures}

The experimental campaign focused upon a commonly used type of enclosure wall used as a single leaf wall or as the outer leaf of cavity enclosure wall - horizontally hollowed clay brick masonry wall.

In Fig. 4, instrumentation and preparation of testing is illustrated clearly, indicating the position of the electrical strain gauges bonded to the specimens.

Wall specimens tested were constituted by horizontally hollowed clay bricks (of common use and format $30 \times 20 \times 15$ ) as the principal masonry unit and "all purpose mortar" for masonry joints. The properties of these units (bricks) were duly characterised, and revealed an average compression strength of $3.91 \mathrm{~N} / \mathrm{mm}^{2}$.

The mortar used in joint bedding (width $=10-12 \mathrm{~mm}$ ) has as volumetric proportion of specific materials (cement: hydrated lime: sand) $1: 1: 51 / 2$ and was also promptly characterised in relation to its mechanical properties. In accordance to EC6 [10] it was classified as M5; in accordance to BS 5628 [11] it was classified as type (iii). 
Specimen dimensions in milimeters

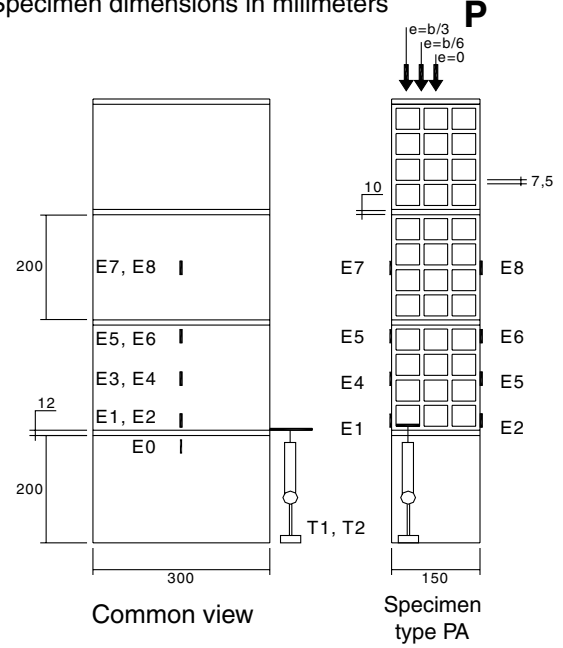

E5

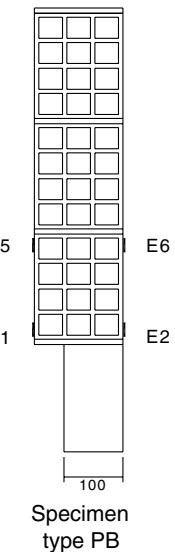

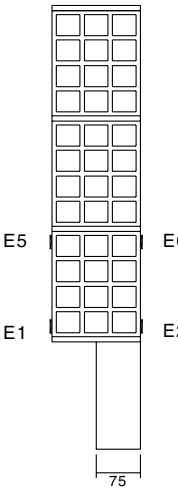

Specimen type PC
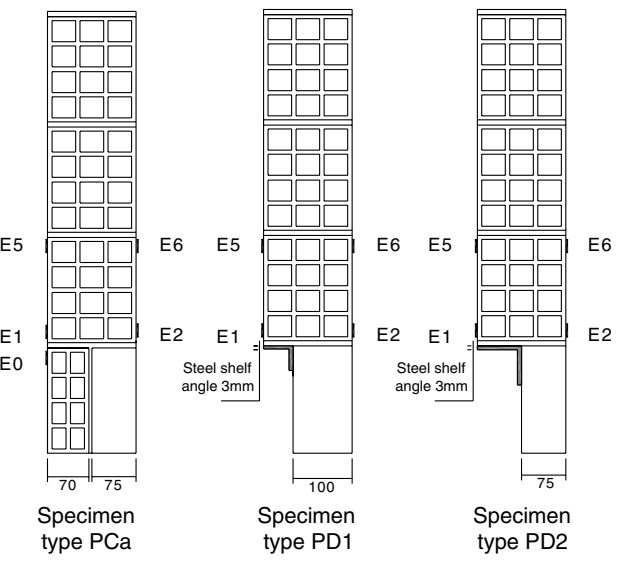

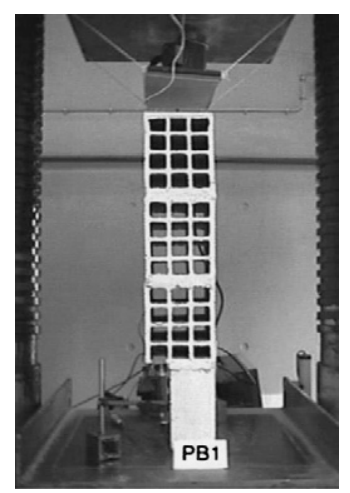

Electric strain gauge $(\mathrm{E})$

Fig. 4. Geometry and instrumentation of wall specimens.

Concrete base supports used on the specimens to simulate different support conditions, proved to be very stiff and compact compared to the masonry unit, and do not influence specimen testing results.

Planning operations of bricklaying and making of the specimens, such as correct preparation and workability of mortar to suit the type of bricks, width control of mortar bed joints and laboratory drying conditions were considered and carefully foresighted.

All tests were carried out at the Civil Engineering Department of the Faculty of Sciences and Technology

of the University of Coimbra, using a press machine "Amsler" of 5000KN (500 tons), with two plates, in which the top plate is hinged.

In order to allow observation and register of the evolution of cracking of the different wall specimens, we loaded the specimens at a fairly low constant displacement rate of $0.01 \mathrm{~mm} / \mathrm{seg}$.

Specimen type PA1 was fully instrumented with strain gauges 1-8; specimens PA2 and PA3 were instrumented only with strain gauges 3 and 4; on specimens type PB1, PC1, PD1 and PD2 we applied only strain gauges 1, 2, 5 and 6; on specimen type PCa we applied strain gauges 0 , 1, 2, 5 and 6 (see Fig. 4).

To evaluate wall behaviour, several parameters were selected: instant and final load values (through a load cell), vertical strains at fixed points on surfaces of both sides of specimens (using unidirectional strain gauges) and displacements at monitored points (using displacement transducers).

The detection of cracking and type of failure suffered by each specimen with load, was only possible due to a videotape recording of tests and to a light white painting of specimens.

All recorded parameters were monitored second by second and all data was stored using a "datalogger TDS 602" where strain gauges, displacement transducers and load cells were connected.

\section{Experimental results}

\subsection{Introduction}

In this paper, only results of specimens PA1, PB1, PC1, PC1a, PD1 and PD2 (specimen types PD partially supported by steel shelf angle with $3 \mathrm{~mm}$ width), subjected to centred vertical compression loading conditions and specimens PA2 and PA3 subjected to eccentric loading conditions will be displayed, discussed and compared.

\subsection{Specimen type PAI}

This wall specimen (PA1) with total basal support is a reference for comparison of further tests. In Fig. 5, we can observe the failure sequence of specimen PA1.

The failure configuration recorded and the cracking of specimen PA1, clearly shows that the opening of cracks occurs at the intersection of inner septums of the brick, in random zones, revealing that there are very susceptible
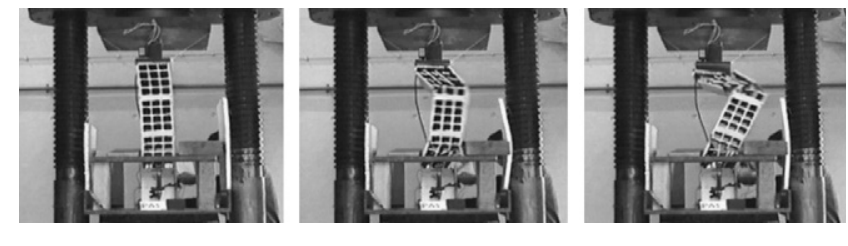

Fig. 5. Failure sequence of specimen PA1. 
Table 1

Results for specimen PA1

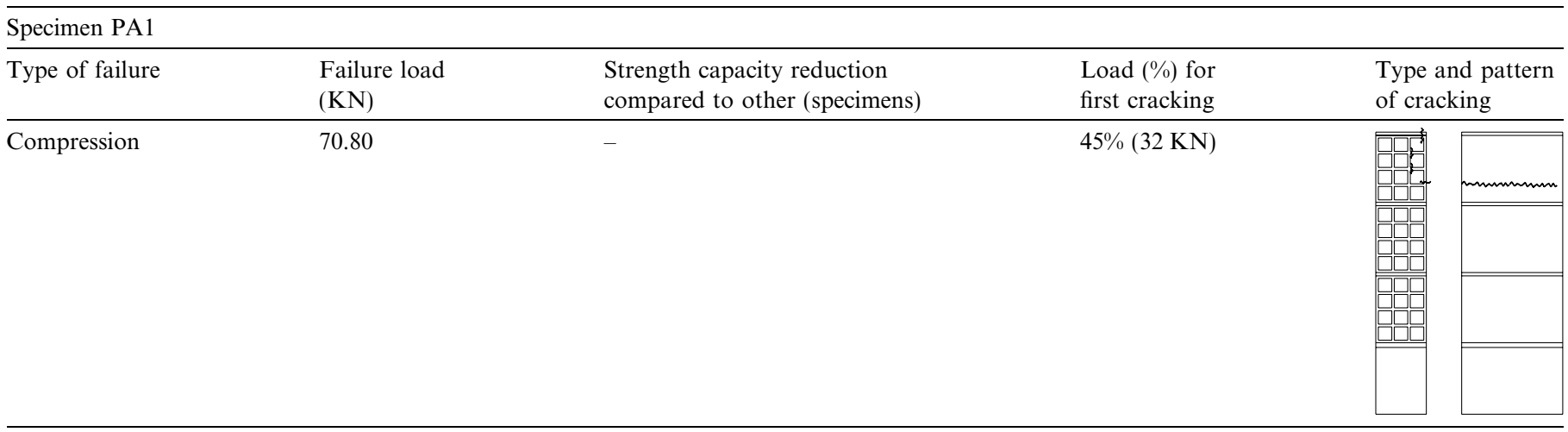

and sensitive areas, such as the corners and recesses of the cavity cells of the clay brick.

Observing failure evolution of this specimen we realise that the fragility and geometry of these units (clay bricks) rule the establishment and comprehension of cracking patterns. The main results of this test are shown in Table 1 and Fig. 6.

According to Fig. 6, all strains are negative and normally increase when nearer to the concrete base support. But in this case the disturbance of strain gauge readings during testing is very noticeable (E1, E7, E6) when cracking occurs aggravated by its level of intensity and damage.

\subsection{Specimens type $P A 2$ and $P A 3$}

Specimen PA2 was eccentrically loaded (eccentricity $=b / 6)$ with $b$ being the width of the wall specimen, this eccentricity establishes the limit of the central nucleus. To better evaluate the influence of increasing eccentricity of loading, the load applied over specimen PA3 was also eccentric with the higher value of eccentricity $=b / 3$.
Table 2

Results for specimen PA2, PA3

\begin{tabular}{lllll}
\hline \multicolumn{2}{l}{ Specimen PA2, PA3 } & & \\
\hline Specimen & $\begin{array}{l}\text { Type of } \\
\text { failure }\end{array}$ & $\begin{array}{l}\text { Failure } \\
\text { load } \\
(\mathrm{KN})\end{array}$ & $\begin{array}{l}\text { Strength capacity } \\
\text { reduction compared } \\
\text { to other (specimens) }\end{array}$ & $\begin{array}{l}\text { Load }(\%) \\
\text { for first } \\
\text { cracking }\end{array}$ \\
\hline PA2 & Compression & 89.97 & $+27 \%($ PA1) & $46 \%(41 \mathrm{KN})$ \\
PA3 & Compression & 38.77 & $-45 \%($ PA1 $)$ & $85 \%(33 \mathrm{KN})$ \\
\hline
\end{tabular}

From the results of Table 2, there are two major observations to be displayed. First; the increasing of the eccentricity of loading, compromises severely strength capacity of the wall due to cracking occurring at an earlier stage. Secondly; the higher failure load registered for specimen PA2 when compared with specimen PA1 (centred loading conditions), reveals the existence of stress-load paths, aggravated by the geometry of the clay brick.

According to Figs. 7 and 8, the strain level for strain gauge 2 of specimen PA2 is higher than on specimen PA3, which has greater eccentricity of load, this result can be explained by the way the load is applied on both

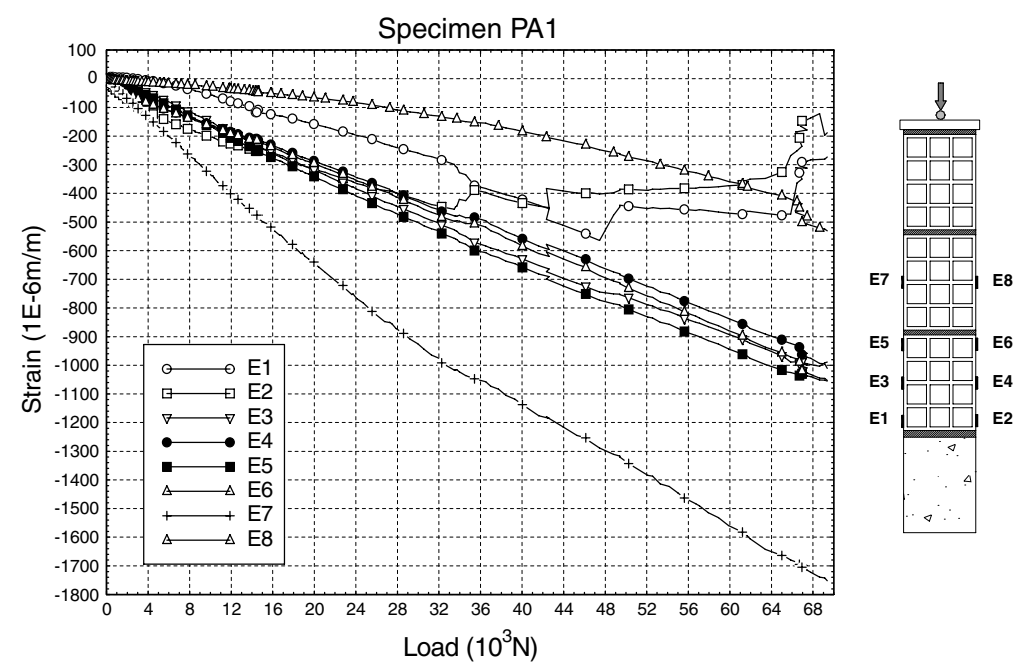

Fig. 6. Vertical strains for specimen PA1. 

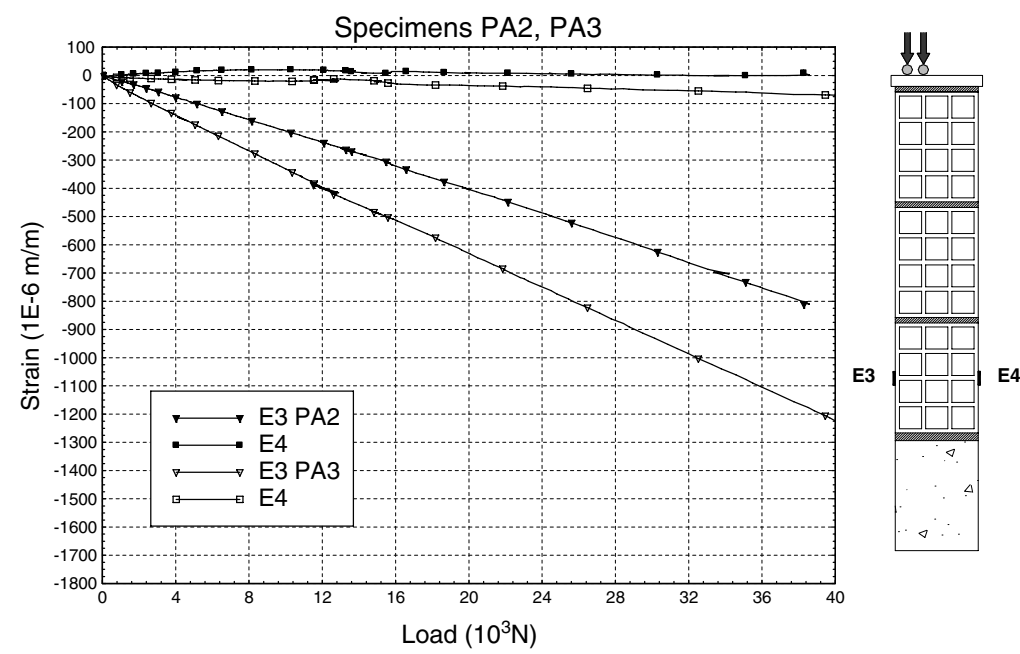

Fig. 7. Vertical strains for specimens PA2 and PA3.
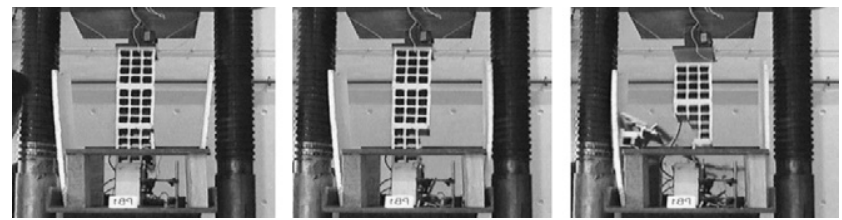

Fig. 8. Failure sequence of specimen PB1.

specimens due to their correspondent eccentricity values (see Fig. 4), the loading conditions for specimen PA2 create a privileged stress-path through the a inner septum alignment. Furthermore if we compare the difference between the strain gauge values on both sides of both specimens, we notice higher differentiability of strain values for specimen PA3.

\subsection{Specimen type PBI}

Regarding specimen type PB1, failure mode and cracking do not occur in such a random and indefinable way such as in specimen PA1. Cracking does begin mostly above the $2 / 3$ supported breadth of the wall, at the intersection of septums and near the lower brick region - transition of support conditions (see Table 3).

Fracture and cleaving of the lower brick are noticeable and they are clearly responsible for the final failure. Positive strains values registered by strain gauge 1 , even though very small, $(50 \mu)$ reveal a positive tension state over that unsupported area (see Figs. 9 and 10).

\subsection{Specimen type $P C 1$}

Through specimen PC1 tests, we observed very compromising rotation phenomena, which influences very clearly failure configuration and cracking evolution. Cracking appears very seriously and critical at the region of transition of support conditions because of internal shear forces instated and, also, at mortar bed joints as a consequence of rotation (see Fig. 11).

Very high tension stresses at the corners of cavity brick cells and horizontal septums are responsible for cracking,

Table 3

Results for specimens type PB1

\begin{tabular}{llll}
\hline Specimens type PB1 & $\begin{array}{l}\text { Failure load } \\
\text { Type of failure }\end{array}$ & $\begin{array}{l}\text { Strength capacity } \\
\text { reduction compared } \\
\text { to other (specimens) }\end{array}$ & $\begin{array}{l}\text { Load (\%) for first } \\
\text { cracking }\end{array}$ \\
\hline Compression/fracture/cleaving & 62.27 & $-14 \%$ (PA1) & $\begin{array}{l}\text { Type and pattern of } \\
\text { cracking }\end{array}$ \\
\hline
\end{tabular}




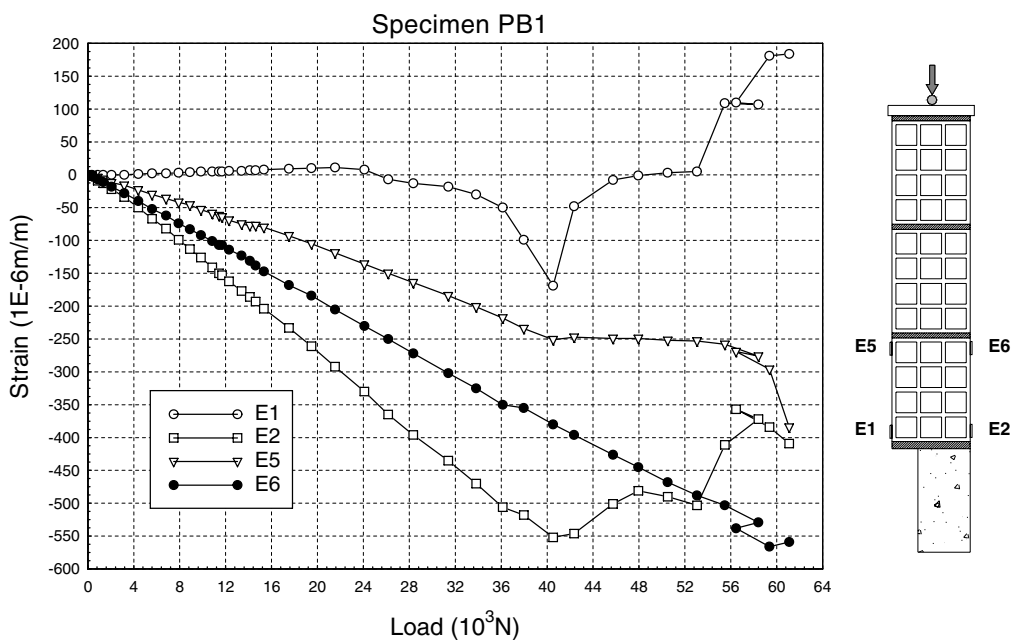

Fig. 9. Vertical strains for specimen PB1.

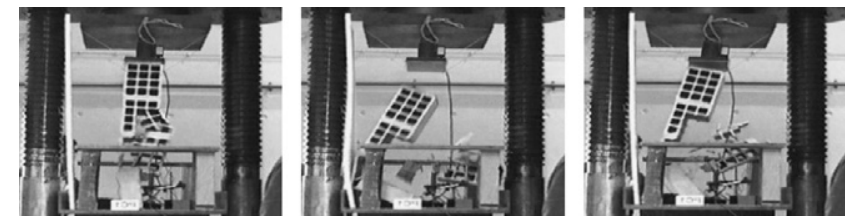

Fig. 10. Failure sequence of specimen $\mathrm{PC} 1$.
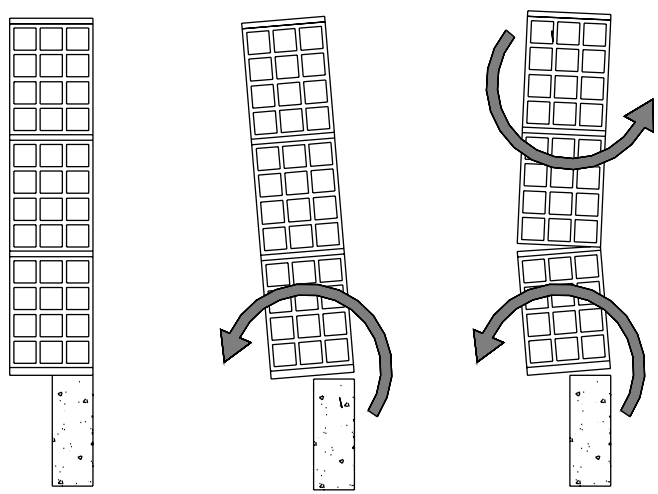

Fig. 11. Rotation phenomena of specimen PC1. due to clay material being less resistant to tension then to compression.

Strain analysis (see Fig. 12) shows a lower level of strain values at strain gauges 2 and 5 in comparison with specimens PB1 and PA1, as a consequence of an allowable flexibility and internal adjustment of the wall specimen. These support conditions are responsible for a very significant reduction of strength capacity (see Table 4). Once this specimen cracks, the aggravation of opened cracks leads to quick failure.

\subsection{Specimen type PCla}

The test results for specimen PC1a are presented in Figs. 13 and 14 and also in Table 5.

The type of failure and the appearing of cracking are similar to specimen PA1. First cracking occurs for values of load under $50 \%$ of failure load, suggesting that the opening of cracks is not so severe as revealed with specimen type PC1. Experimental tests showed that the difference between strain values on the supported side over the ceramic

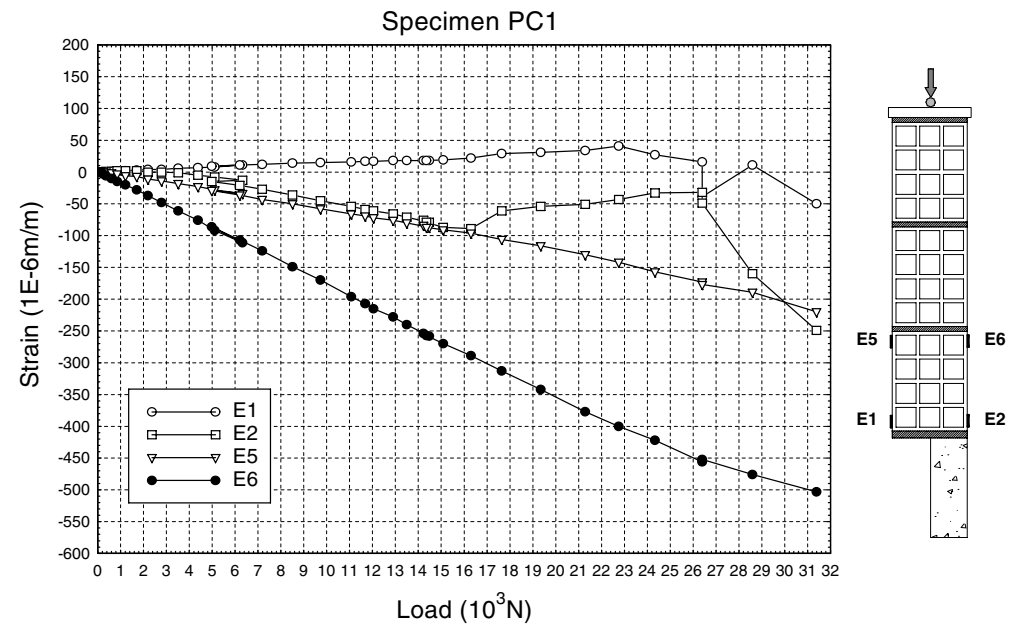

Fig. 12. Vertical strains for specimen PC1. 
Table 4

Results for specimens type PC1

\begin{tabular}{|c|c|c|c|c|c|}
\hline \multicolumn{6}{|c|}{ Specimens type $\mathrm{PC} 1$} \\
\hline Type of failure & $\begin{array}{l}\text { Failure load } \\
(\mathrm{KN})\end{array}$ & $\begin{array}{l}\text { Strength capacity } \\
\text { reduction compared } \\
\text { to other (specimens) }\end{array}$ & $\begin{array}{l}\text { Load }(\%) \text { for first } \\
\text { cracking }\end{array}$ & \multicolumn{2}{|c|}{$\begin{array}{l}\text { Type and pattern o } \\
\text { cracking }\end{array}$} \\
\hline Fracture/cleaving & 42.21 & $\begin{array}{l}-41 \%(\mathrm{PA} 1) \\
-32 \%(\mathrm{~PB} 1) \\
-26 \%(\mathrm{~PB} 1 \mathrm{i})\end{array}$ & $50 \%(21 \mathrm{KN})$ & 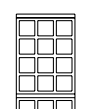 & \\
\hline Fracture/cleaving & 31.59 & $\begin{array}{l}-55 \%(\mathrm{PA} 1) \\
-50 \%(\mathrm{~PB} 1) \\
-45 \%(\mathrm{~PB} 1 \mathrm{i})\end{array}$ & $69 \%(22 \mathrm{KN})$ & 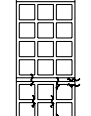 & \\
\hline
\end{tabular}

element is greater than the values recorded on the opposite side (concrete base).

\subsection{Specimen type PD1 and PD2}

The use of steel complementary shelf angles, screwed to the concrete base supports, proved to be efficient and reliable in respect to final strength capacity and first cracking, but in terms of material compatibility to movements - the mortar bond with the steel angle is easily broken - seems

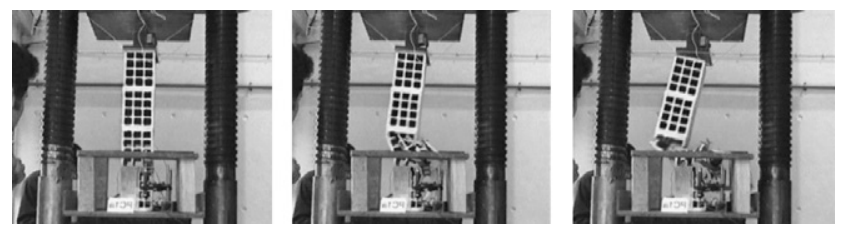

Fig. 13. Failure sequence of specimen PCla. very weak, unpredictable and problematic (see Figs. 15 and 16). During testing, the use of the steel shelf angle did not prevent tension and positive strain values at strain gauge 1 and 5, even though very small (see Fig. 17).

Cracking of specimen PD13mm, as shown in Table 6, occurs at the lower brick - at the interface of transition of support conditions - revealing that this clay brick is surely the weakest and most fragile component of this wall specimen, compromising strongly wall behaviour.

Specimen type PD23 mm, presented reasonable results, but more simulations and variation of thickness of steel angles are important to make solid conclusions. However, it is quite important to note that even though the thickness of adopted steel shelf angles is inferior to those usually used in construction industry; they have a significant contribution over the linearity of deformation and strain evolution against load, as shown in Fig. 18.

According to Table 6, strength capacity of specimen PD23 mm is very similar to specimen PA1 value.

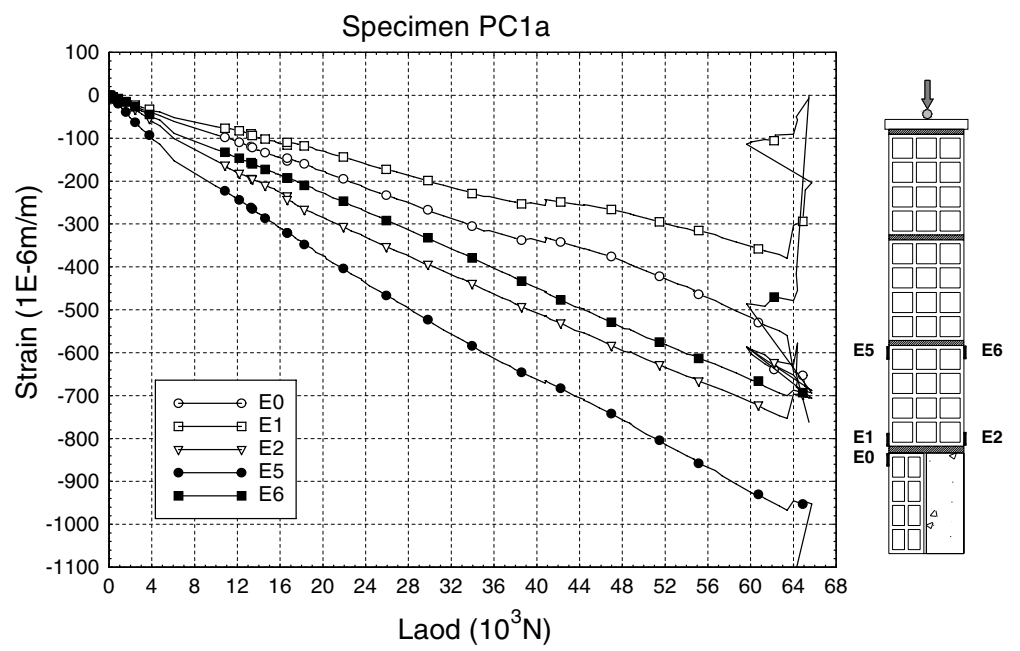

Fig. 14. Vertical strains for specimen PCla. 
Table 5

Results for specimens type PCla

\begin{tabular}{|c|c|c|c|c|c|}
\hline \multicolumn{6}{|l|}{ Specimens type PCla } \\
\hline Type of failure & $\begin{array}{l}\text { Failure load } \\
(\mathrm{KN})\end{array}$ & $\begin{array}{l}\text { Strength capacity } \\
\text { reduction compared } \\
\text { to other (specimens) }\end{array}$ & $\begin{array}{l}\text { Load }(\%) \text { for } \\
\text { first cracking }\end{array}$ & Type : & pattern of cracking \\
\hline
\end{tabular}

Table 6

Results for specimens type $\mathrm{PD} 1_{3 \mathrm{~mm}}$ and $\mathrm{PD} 2_{3 \mathrm{~mm}}$

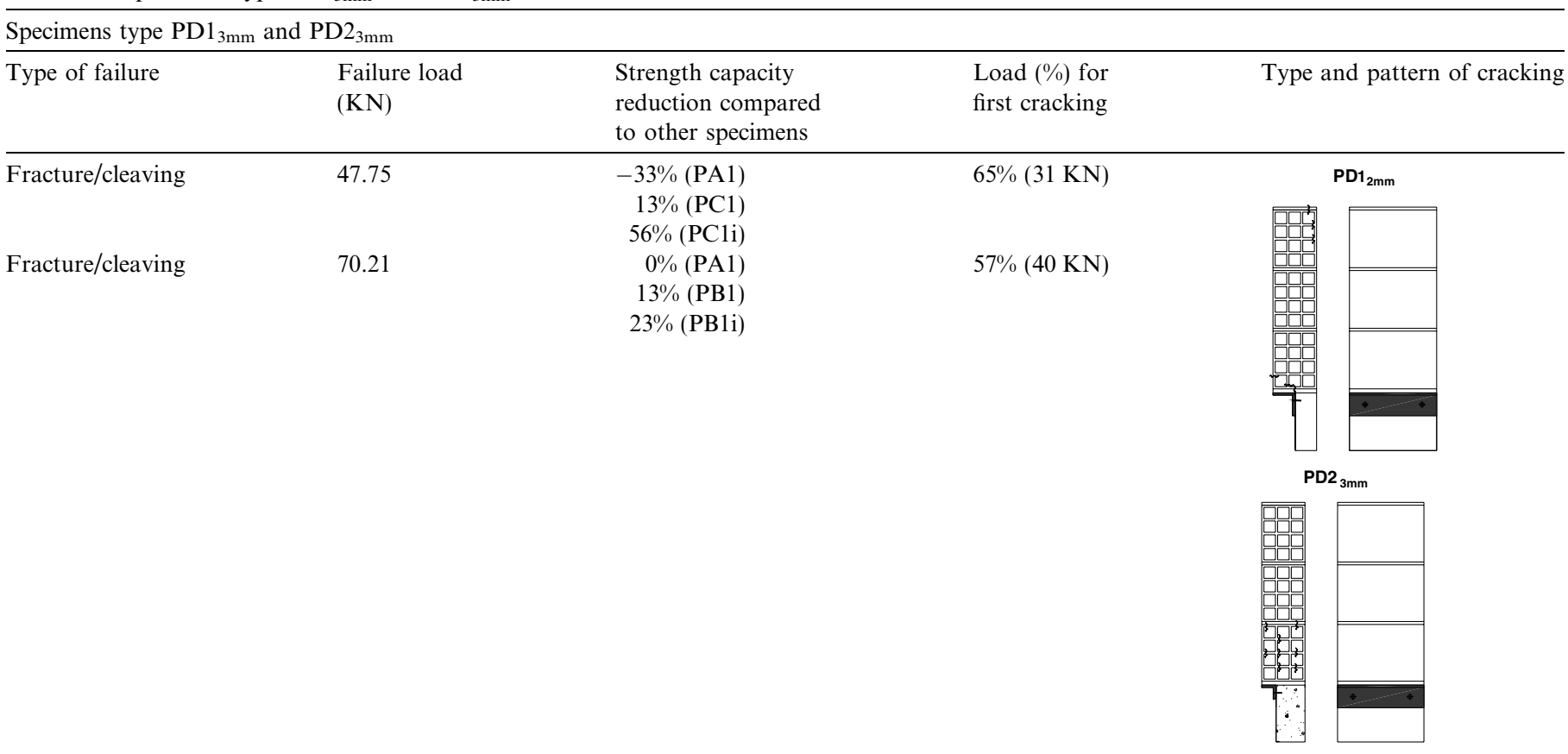

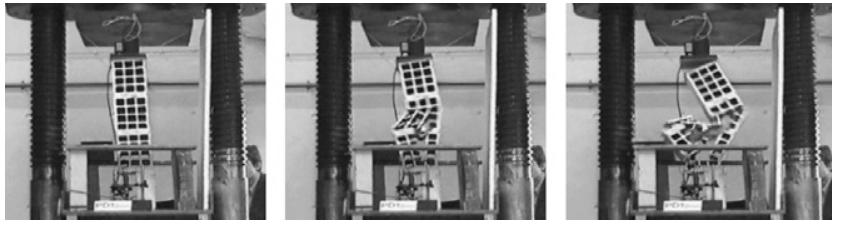

Fig. 15. Failure sequence of specimen $\mathrm{PD} 1_{3 \mathrm{~mm}}$.
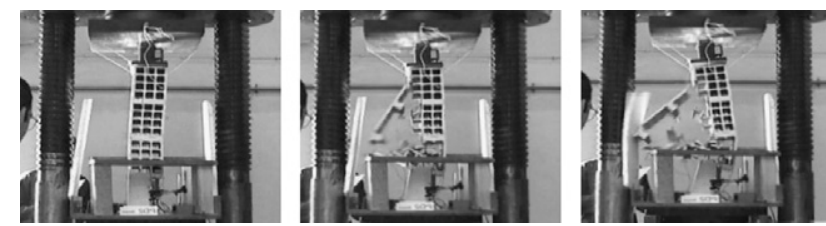

Fig. 16. Failure sequence of specimen $\mathrm{PD} 2{ }_{3 \mathrm{~mm}}$.

\subsection{Vertical displacement of wall samples}

Fig. 19 plots vertical displacement for all wall specimens measured at the same point (outer external void of lower brick).

Comparing recorded displacements among the six specimens studied it is clear that the displacement and rotation phenomena of the wall is increased and aggravated in consequence of the lack of sufficient support of the breadth of the wall.

However these results must be assumed with some precaution, due to early cracking (under small loads) near the monitored displacement point. 


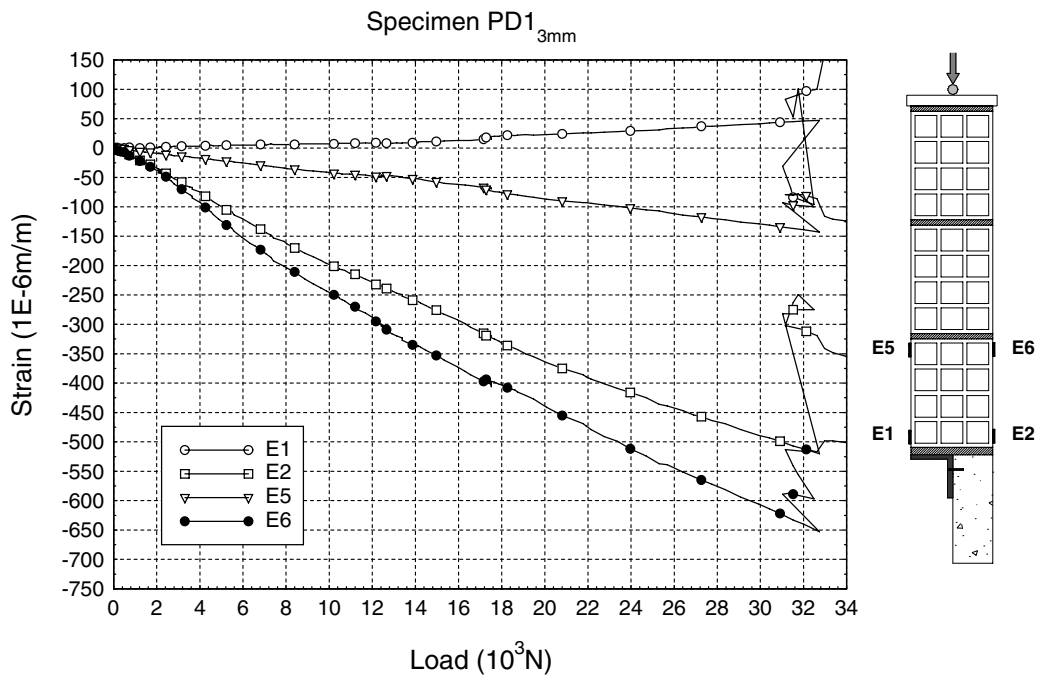

Fig. 17. Vertical strains for specimen $\mathrm{PD} 1_{3 \mathrm{~mm}}$.

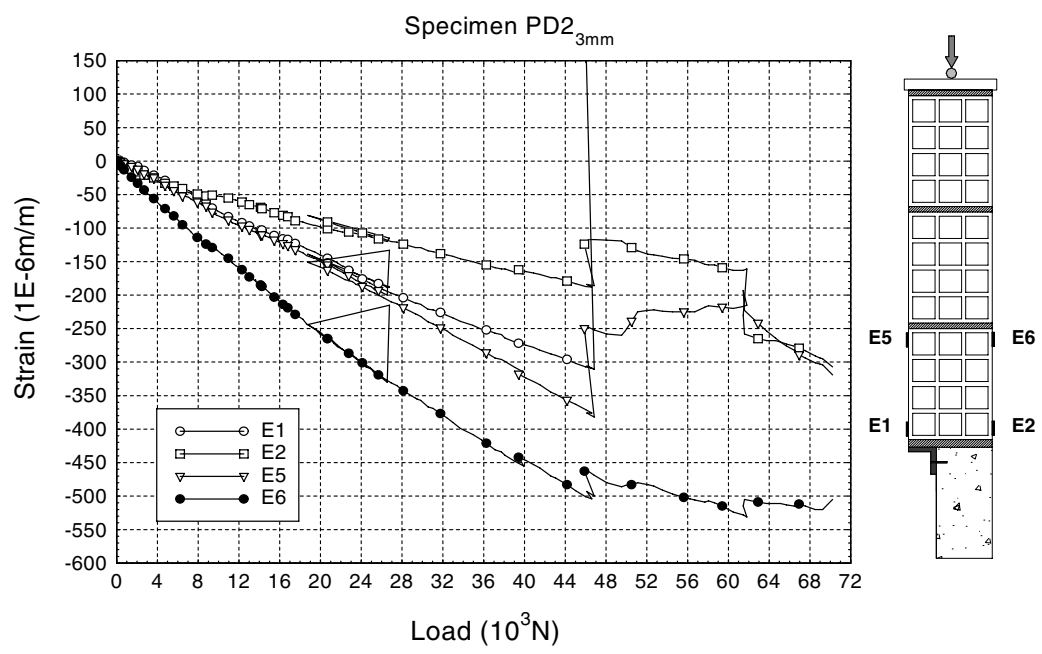

Fig. 18. Vertical strains for specimen PD2 $3 \mathrm{~mm}$.

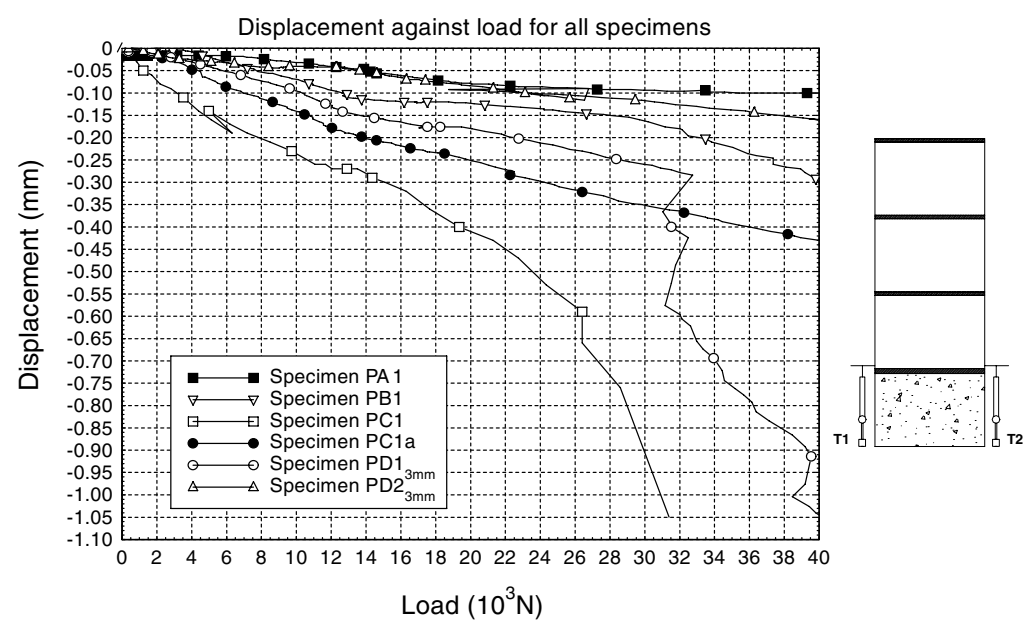

Fig. 19. Comparison of measured displacements of all specimens. 


\section{Numerical approach}

\subsection{Aims of the numerical approach}

Numerical approach - by finite element analysis - is a valuable tool to evaluate local high stresses and to establish their relation with cracking and failure shape mode. Observed cracking and its evolution confirm the instated computed tension stresses and the strain values at specific areas of wall specimens.

The numerical approach was carried out only for specimens type PA1, PB1, PC1, PC1a.

The knowledge of material characteristics is very important for any FEM analysis. Table 7 summarizes median elastic properties usually used in numerical simulation for clay brick, mortar and concrete. All materials were considered homogeneous with linear elastic behaviour.

To assess and interpret the behaviour and cracking of the wall specimens it was carried out a linear elastic analysis, considering a plane stress state using $2 \mathrm{D}$ continuum isoparametric elements of eight nodes (see Fig. 20).

Once we created the macro-elements, the FEM model was successively meshed and refined to a degree in with strain and stress results were satisfactory. The final mesh spacing adopted was $\mathrm{d} x=2.5 \mathrm{~mm}$ and $\mathrm{d} y=2.5 \mathrm{~mm}$ (see Fig. 20). All diagrams shown further are based on a $25 \mathrm{KN}$ acting load on the top face of the modelled specimens.

\subsection{Finite element analysis results}

The FEM analysis produced results of internal stresses $\left(\sigma_{x}, \sigma_{y}, \sigma_{\min }, \sigma_{\max }, \tau_{x y}, \tau_{\max }\right)$ and strains $\left(\varepsilon_{x}\right.$ and $\left.\varepsilon_{y}\right)$.

In order to understand stress concentration that leads to cracking, we will analyse stress results, of three transverse sections indicated in Fig. 21. All sections are related to the lower of each specimen: section (i) corresponds to its top mortar joint; section (ii) is located at mid - height of the brick, across an horizontal clay septum; at last section (iii) is located at its bottom mortar joint. Fig. 21 represents the typical output of FEM software, which is difficult to visualize in greyscale; for this reason we have selected another kind of graphics adopted in Figs. 22 and 23.

\subsection{Comparison of stress plots}

Through Figs. 22 and 23, we can compare the relative levels of stress at the different transverse sections. A first notice is to the symmetry or asymmetry of stresses within the specimens with different support conditions.

Table 7

Elastic properties of materials

Clay (brick units)

Mortar (joints)

$E=8.3 \times 10^{3} \mathrm{MPa}, v=0.2$

Concrete (base support)

$E-$ Young's modulus, $v$ - Poisson coefficient
Maximum values of stress $\left(\sigma_{x}\right)$ attained for all four specimens reach local stress peaks, but only specimens PB1 and PC1 reach superior values around $1.3-1.6 \mathrm{~N} / \mathrm{mm} 2$, about three to four times higher when compared to specimen PA1 and PCla.

Stress plots for specimens PC1a and PA1 are very similar, but in consequence of basal support conditions of spec-
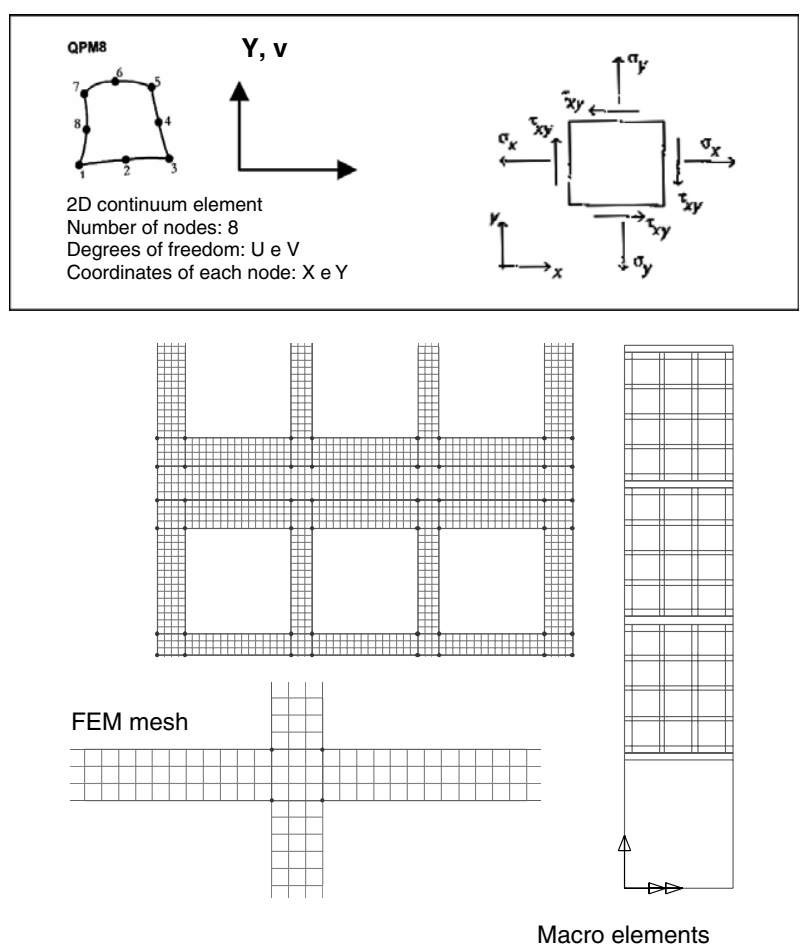

Fig. 20. Description of FEM element and mesh.

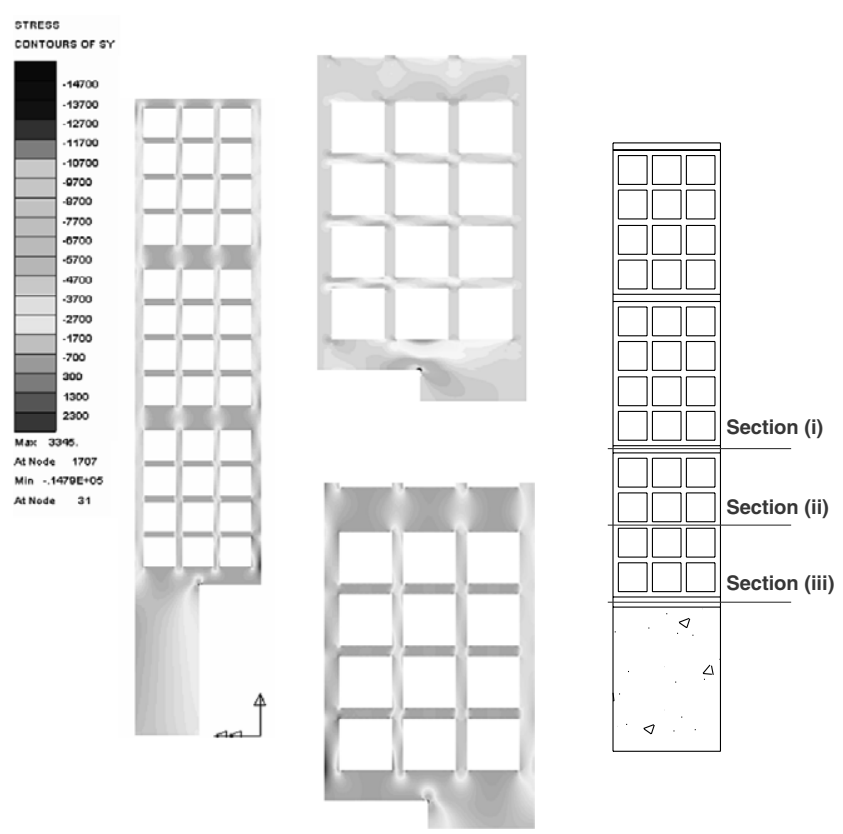

Fig. 21. Examples of computed stress output by FEM. 

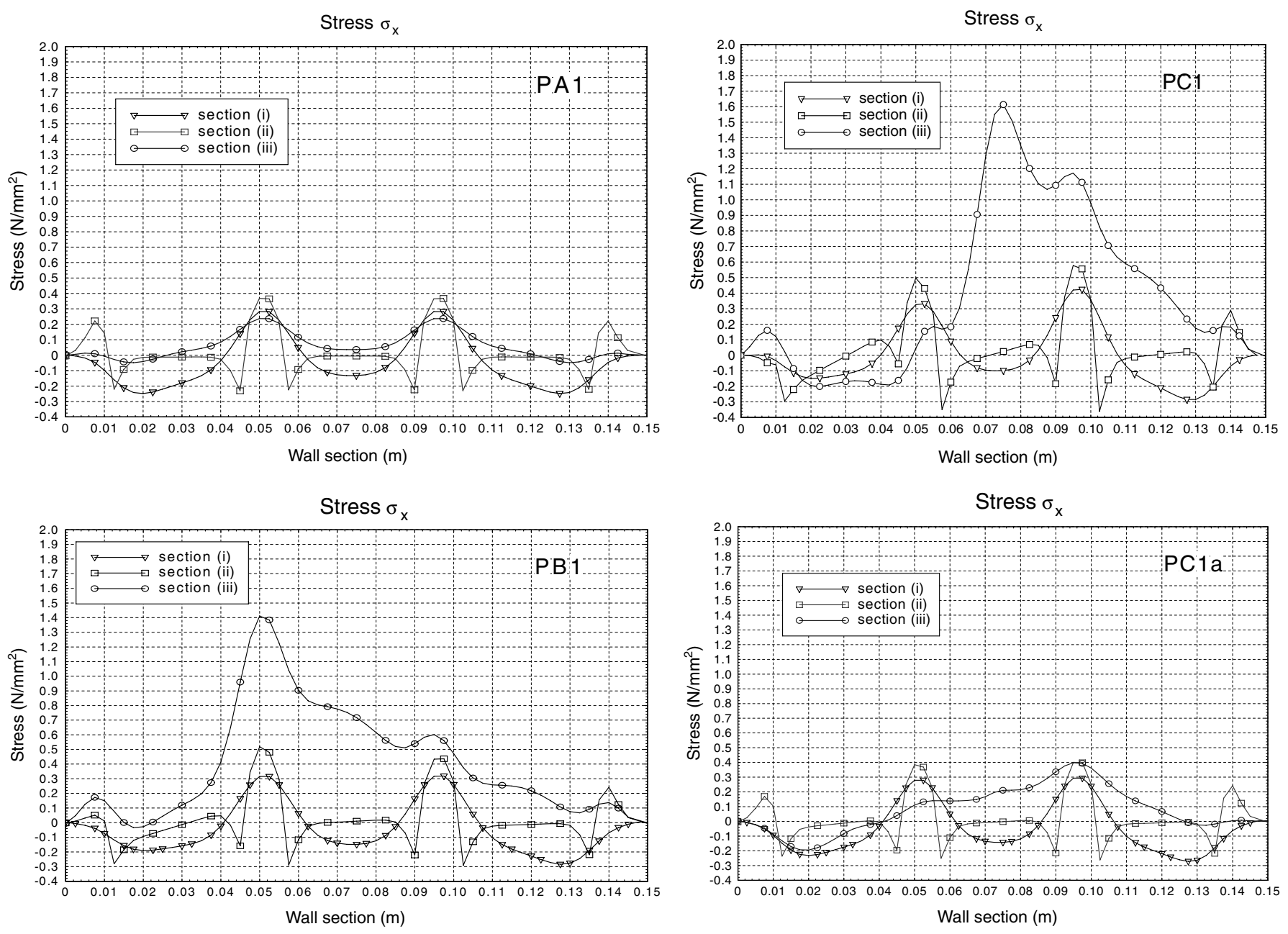

Fig. 22. Stress plots $\left(\sigma_{x}\right)-$ at three transverse sections.

imen PC1a, we obtain higher values of stress $\left(\sigma_{x}\right.$ and $\left.\sigma_{y}\right)$ around the supported side over the concrete base.

Results are coherent and consistent with observations made at the experimental phase, in relation to stress peaks at specific areas of specimens (intersection of internal septums and at transition region of basal support).

As we know, clay material does not support very high tension stresses and, as a result of this, we can explain the appearing of cracking at horizontal septums.

Stress at section (i) - mortar bed between bricks - shows that stress levels are diminished and low. Geometry of the clay brick regulates and commands stress and strain distribution, within the specimens.

Through this FEM analysis, some comments and conclusions were brought forward and are described in the next section.

\section{Conclusions}

In the previous sections we have reported and discussed several aspects related to Portuguese buildings, particularly, about defects resulting from inadequate correction of thermal bridges, using external clay brick walls. We state now the main conclusions of this paper and of the supporting research, exceeding, occasionally, the limits of the exposed results.

In what concerns the experimental approach carried out, not only on clay brick units and mortar, but also on masonry wall samples, we can conclude as follows:

- The geometry of clay brick units (with high horizontal perforation) and their heterogeneity are very relevant to the final masonry strength, except in case of reduced supports or in case of quite eccentric loads;

- The support conditions, when partial, strongly affect the final strength of the walls and the way they crack (severity, pattern, etc.). For specimens in which loading was applied eccentrically, produced lower strength capacities and severer cracking states.

- For specimens type PB1, around 57\% of the failure load, first cracking appears. In this case cracking occurs at fragile points (internal septum's) in not such a comprehensive matter. For specimens type PC1, the cracking and failure mechanism is clearer, as can be observed a 

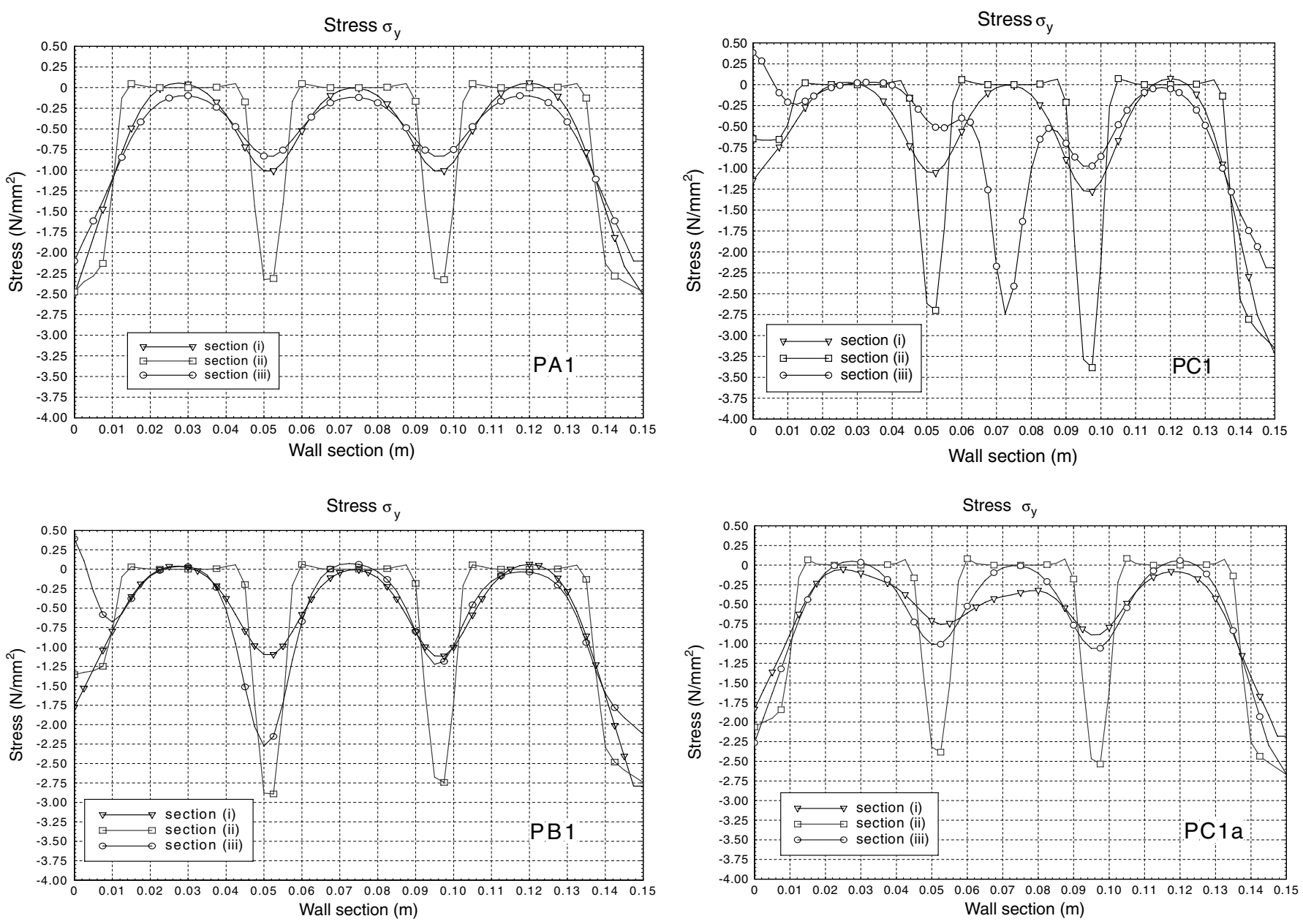

Fig. 23. Stress plots $\left(\sigma_{y}\right)-$ at three transverse sections.

rotational mechanism after crack opening due too excessive tension at the bed joint level. For specimen type $\mathrm{PC} 1$, experiences first cracking for very high values of the failure load, about $69 \%$. This characteristic most not be overlooked, because first cracking, might in some cases lead to failure quickly;

- The reduction of strength capacity of specimen PB1 is about $14-24 \%$ in relation to specimen PA1 (full basal support). Increasing the non supported section, as in the case of specimens type PC1 the reduction increases to around $40-50 \%$;

- The cracking phenomena for specimen PA1, PC1a are essentially to excessive compression state, for specimens PC1, PD1 and PD2 severe cracking occurs at the lower brick revealing fracture and cleaving failure.

- The minimum partial support of the walls should be about $2 / 3$ of wall thickness, as indicated in French codes (D.T.U 20.1) [12];

- Using a steel shelf angle as an additional support (specimens PD1 and PD2), revealed to be beneficial, increasing the final strength of the wall; however, these results are contradictory to several real construction defects.
The main conclusions obtained from numerical analysis are the following:

- Results are very complying with the experimental work. Stress concentration occurs at areas where cracking was observed during the experimental campaign;

- Specimen basal support conditions influence deeply the stress distribution within the specimen and particularly at the intersection of septums;

- Existence of similarity of strain and stress values of specimens PA1 and PC1a;

- For specimens type PB1 and PC1, the partial basal support conditions at the lower brick and the intersection of internal septums of the horizontally hollowed brick are the most fragile due to tension stresses installed that are not capable of being beared by clay material. High tension stresses developed in the clay material at the region of support transition conditions compromises final strength of specimen PB1 and PC1;

- The distribution and relief of stress near the mortar bed joints between bricks that occurs from the vertical 
tension driven through the internal septums (spreading effect);

- The tension stresses developed at the lower brick near the transition region of specimen $\mathrm{PB} 1$ are roughly 60 $70 \%$ of the values of tension stress of specimen $\mathrm{PC} 1$ in the same area;

- Existence of stress-load paths, aggravated by the geometry of the clay brick (orthogonal and aligned septums);

- Validation of a simplified model of behaviour using finite element analysis is a future coming goal.

It is necessary to make more research efforts to get solid technological conclusions on this matter. Nevertheless, we can underline so far some technological guidelines for Portuguese masonry construction:

- It is urgent to promote masonry design, including nonloadbearing design, particularly in what concerns singular points;

- The external correction of thermal bridges, using clay brick walls, is still dangerous, due to the insufficient technological knowledge on this matter;

- The low investment in new brick formats and masonry construction systems do not respond to new demands, compatibility problems. The need to produce special brick formats is necessary;

- The inexistence of normative documents and design tools for non load-bearing walls is evident, but also in other European countries;

- It is obvious that the use of shelf angles and wall ties connecting internal and external leaves should be a common practice, particularly in partially supported walls;

- It is quite important to survey new constructions where external correction of thermal bridges was applied - to learn more about their behaviour and to initiate the eventual rehabilitation process as soon as possible;

- The use of reinforced masonry is not a common practice. The frequent use of confined masonry without the necessary structural normative framing, creating an opportunity to improve non load-bearing masonry and incentive minimally reinforced schemes;

- The encouragement of the use of methods of simplified design and calculus to evaluate stresses and movements due to various factors. Special attention for walls sub- jected to great temperature ranges and wind action $[13,14]$;

- First cracking affects walls water-tightness quite before final failure.

\section{References}

[1] Vicente R. Pathology of masonry enclosure walls. Mechanical behaviour of enclosure walls with external thermal bridge correction, MSc thesis in Civil Engineering, University of Coimbra, 2002 [in Portuguese].

[2] Silva J, Vicente R. Damages and defects of masonry enclosure walls (enclosure wall instability and cracking due to correction of thermal bridges), In: The 7th international conference on inspection, appraisal, repairs \& maintenance of buildings \& structures, 11-13 September, 2001.

[3] Tubi Norberto - La Realizzazione di Murature in Laterizio, Roma. Andil, Sezione Murature, 1986.

[4] Duque V, Tadeu A, Silva J, Meliço S. Illness related to thermal pathologies in buildings. In: International conference on implementation of safety and health on construction sites, CIB W99, Lisboa, Setembro 1996.

[5] Garratt J, Nowak F. Tackling condensation: a guide to the causes of, and remedies for, surface condensation and mould in traditional housing, BRE Report, Garston, 1991.

[6] Portugal - laws, decrees, etc. Portuguese Thermal Code (Regulamento das Características de Comportamento Térmico dos Edifícios. Dec.-Lei $n^{\circ}$ 40/90 de 6 de Fevereiro de 1990).

[7] Abrantes V, Silva J. The new Portuguese building thermal regulations: a passive and low energy approach, PLEA 91 (Passive and low energy architecture congress), Sevilha. In: Alvarez S et al., editors. Architecture and urban space. Kluwer Academic Publishers; 1991. p. 715-20.

[8] Hendry AW, Sinha BP, Davies SR. Design of masonry structures. Load bearing brickwork design, 3rd ed., 1997.

[9] Silva J, Abrantes V, Vicente R, Precocious degradation of enclosure walls with external thermal bridge correction. Case studies, National Congress on Construction, IST, Lisbon, December, 2001 [in portuguese].

[10] CEN, Eurocode 6, Design of masonry structures - Part 1-1: General rules for buildings - Rules for reinforced and unreinforced masonry. CEN, prENV 1996-1-1, 1995.

[11] BSI, BS 5628 - code of practice for use of masonry. Part 1: Structural use of unreinforced masonry, BSI, London, 1992.

[12] CSTB (Groupe de Coordination des Textes Techniques) - DTU 20.1 (référence AFNOR DTU P10-202) - Parois et murs en maçonnerie de petits éléments. Cahier CSTB 2024, livraison 262, CSTB, Paris, Septembre 1985 .

[13] CIB - W23 - International recommendations for design and erection of unreinforced and reinforced masonry structures with an appendix on recommendations for seismic design of unreinforced, confined and reinforced masonry structures. Publication 94. CIB, Rotterdam, 1987.

[14] John H. Matthys, editor, TMS - The Masonry Society; ACI, American Concrete Institute; CMR - Council for Masonry Research - Masonry Designers' Guide. 1st ed., 1993, Boulder (CO), 1993. 